\title{
Effects of soil and space on the woody species composition and vegetation structure of three Cerrado phytophysiognomies in the Cerrado-Amazon transition
}

\author{
L. Maracahipes-Santos ${ }^{a, b *}$, E. Lenza ${ }^{b, c}$, J. O. Santos ${ }^{b}, H$. A. Mews ${ }^{d}$ and B. Oliveira ${ }^{b}$ \\ ${ }^{a}$ Instituto de Pesquisa Ambiental da Amazônia - IPAM, Rua Horizontina, 104, CEP 78640-000, Canarana, MT, Brazil \\ 'Programa de Pós-graduação em Ecologia e Conservação, Universidade do Estado de Mato Grosso - UNEMAT, CP 08, \\ CEP 78690-000, Nova Xavantina, MT, Brazil \\ 'Curso de Ciências Biológicas, Universidade do Estado de Mato Grosso - UNEMAT, CP 08, CEP 78690-000, \\ Nova Xavantina, MT, Brazil \\ ${ }^{\text {d} C e n t r o ~ d e ~ C i e ̂ n c i a s ~ B i o l o ́ g i c a s ~ e ~ d a ~ N a t u r e z a, ~ U n i v e r s i d a d e ~ F e d e r a l ~ d o ~ A c r e ~-~ U F A C, ~ C P ~ 500, ~ C E P ~ 69920-900, ~}$ \\ Rio Branco, AC, Brazil \\ *e-mail: maracahipes@hotmail.com
}

Received: February 17, 2016 - Accepted: May 16, 2016 - Distributed: November 31, 2017

(With 4 figures)

\begin{abstract}
The Cerrado Biome is considered one of the world's biodiversity hotspots because of its rich biodiversity, the high level of endemism and the increasing threat. The Cerrado is composed by a mosaic of different vegetation types, including physiognomies that vary from grasslands (campo limpo) to savannas (typical cerrado or cerrado sensu stricto) and cerrado woodlands (cerradão). However, the factors that determine the composition of the Cerrado's flora and the structure of the physiognomies that compose this biome are still poorly understood. Here, we investigate the influence of the chemical and granulometric properties of the soil and the effect of geographic distance on the occurrence and abundance of woody species in three Cerrado phytophysiognomies - cerrado woodland (cerradão), dense cerrado savanna and typical cerrado savanna - in the Cerrado-Amazon transition. We tested the hypothesis that the edaphic characteristics and geographic space determine the species composition and the structure of the woody vegetation of these three phytophysiognomies. We demonstrate that the dissimilarities in the structure and composition of the three sites were determined more by space (13\% of explanation) than edaphic properties (1\%), but primarily by the interaction between these two factors $(26 \%)$. We conclude that, in situations where the chemical and granulometric properties of the soil are relatively homogeneous, as we found in the present study, geographic distance between sites has a greater influence than variation in the substrate's properties on modelling the occurrence and abundance of the woody plant species in the Cerrado.
\end{abstract}

Keywords: cerradão, edaphic properties, geographical distance, soil-vegetation relationship, species composition.

\section{Efeito do solo e do espaço sobre a composição de espécies lenhosas e estrutura da vegetação de três fitofisionomias de Cerrado na transição Cerrado-Amazônia}

\begin{abstract}
Resumo
O Bioma Cerrado é considerado um dos "hotspots" mundiais de biodiversidade devido à rica biodiversidade que abriga, ao elevado nível de endemismo e à eminente ameaça. O Cerrado é composto por um mosaico de diferentes tipos de vegetação e inclui fisionomias que variam desde áreas predominantemente graminosas (campo limpo) a savanas (cerrado típico ou cerrado sensu stricto) e florestas (cerradão). Entretanto, os fatores que determinam a composição da flora do Cerrado e a estrutura das fisionomias que o compõem ainda são pouco compreendidas. Aqui, nós avaliamos a influência das propriedades químicas e granulométricas do solo e da distância geográfica sobre a ocorrência e abundância de espécies lenhosas em três fitofisionomias do Cerrado - cerradão (CO), cerrado denso (DC) e cerrado típico (TC) - na transição Cerrado-Amazônia. Nós testamos a hipótese de que as características edáficas e o espaço determinam a composição florística e a estrutura da vegetação lenhosa das três fitofisionomias. Nós demostramos que a dissimilaridade florístico-estrutural entre os três sítios foi mais determinada pelo espaço ( $13 \%$ da explicação) do que pelas propriedades edáficas ( $1 \%$ ) e principalmente pela interação entre solo e espaço (26\%). Concluímos que, em locais onde as propriedades químicas e granulométricas dos solos são relativamente homogêneas, como no presente estudo, a distância geográfica entre sítios tem mais efeito do que o substrato sobre a ocorrência e abundância de espécies lenhosas de Cerrado.
\end{abstract}

Palavras-chave: cerradão, propriedades edáficas, distância geográfica, relações solo-vegetação, composição florística. 


\section{Introduction}

The high plant diversity of the Cerrado, with approximately 12,350 species catalogued by Mendonça et al. (2008), and 12,097 Angiosperms, 269 ferns and Lycophytes and 478 Bryophytes catalogued by Zappi et al. (2015), Prado et al. (2015) and Costa and Peralta (2015), has been attributed to the considerable environmental heterogeneity of this biome (Felfili et al., 2008). On a regional scale, relief (Motta et al., 2002; Silva et al., 2006), altitude (Motta et al., 2002), climate (Silva et al., 2006), and historical variation in climatic conditions (Oliveira-Filho and Ratter, 1995, 2002) have likely influenced the occurrence and abundance of species. On a local scale, edaphic properties (Ribeiro and Walter, 2008; Reatto et al., 2008), the occurrence of wildfires (Hoffmann et al., 2012), and relief (Oliveira-Filho et al., 1989) are important predictors of the distribution of the vegetation of the Cerrado. Given this, a series of studies over the past few decades have investigated the factors that determine this variation in species richness and composition, as well as the distribution of the vegetation (Eiten, 1972; Oliveira-Filho and Ratter, 1995; Furley, 1999; Silva et al., 2006), in order to better understand the local and regional factors involved.

The vegetation of the Cerrado Biome is dominated by savannas on well-drained and deep, but dystrophic soils (Ribeiro and Walter, 2008; Reatto et al., 2008). Forest physiognomies in the Cerrado, by contrast, cover a much smaller area, and are associated with mesotrophic and eutrophic soils (dry forest on limestone) and watercourses, constituting Cerrado woodlands (cerradão), deciduous forests on limestone outcrops (matas secas sobre calcário), and gallery forests and riparian forests on each edaphic environment, respectively (Ribeiro and Walter, 2008). The cerrado woodland, known locally as cerradão, is well-developed physiognomy of the Cerrado. It has, a typical forest-type structure, but its flora is composed predominantly by savanna species (Ratter et al., 1973; Eiten, 1972; Oliveira-Filho and Ratter, 2002; Ribeiro and Walter, 2008). The cerrado woodland also occurs on well-drained soils, which can be either dystrophic or mesotrophic (Ratter et al., 1973; Ribeiro and Walter, 2008).

Traditionally, most authors have pointed to the availability of nutrients in the soil (Ratter et al., 1973; Araújo and Haridasan, 1988), its texture (Marimon-Junior and Haridasan, 2005), and water availability (Oliveira-Filho et al., 1989; Carvalho et al., 2014) as the principal factors determining the variation in the structure and composition of the vegetation on a local scale. A number of studies have also identified in the soil one of the main abiotic factors responsible for the determination of the species diversity and composition, and phytophysiognomic diversification of the Cerrado, which plays a fundamental role in the structuring of its woody vegetation (Haridasan, 2007; Reatto et al., 2008; Mews et al., 2016). Another fundamental factor is the ecological importance of the fire to keep the Cerrado heterogeneity (see Coutinho, 2002). Even so, some studies have found a small relationship between edaphic factors and the species composition and structure of the woody vegetation of the Cerrado biome (Marimon-Junior and Haridasan, 2005; Carvalho et al., 2014). Haridasan (2007) has even proposed that the diversity of Cerrado phytophysiognomies is determined at least as much by the spatial variation in the characteristics of the soil as by spatial patterns.

Given this complexity interaction of soil, space and vegetation, a number of recent studies have focused on the role of spatial predictor variables in their ecological analyses, although this approach is still rare (e.g. Legendre et al., 2002; Peres-Neto and Legendre, 2010; Moro et al., 2015; Neves et al., 2015; Mews et al., 2016), although Mews et al. (2016) used an approach of this type. This new approach may help improve the understanding of the factors and mechanisms that mold the distribution of the flora and the structure of the vegetation of the Cerrado.

In this context, we evaluated the influence of the chemical and granulometric properties of the soil, and geographic distance on the occurrence and abundance of woody species in three Cerrado phytophysiognomies: cerrado woodland, dense cerrado savanna, and typical cerrado savanna, with sparse trees and shrubs (see Eiten, 1972; Ribeiro and Walter, 2008) in the Cerrado-Amazon transition zone. We tested the hypothesis that edaphic properties and spatial autocorrelation (geographic distance) have a synergic influence on the species composition and structure of the woody vegetation of the three phytophysiognomies.

\section{Material and Methods}

\subsection{Study area}

We studied the woody plant communities of three distinct Cerrado phytophysiognomies (sensu Eiten, 1972; Ribeiro and Walter, 2008) located inside a single vegetation fragment at three nearby sites - cerrado woodland, also known as cerradão (hereafter, CO - 1249'26.8” S, 5146’06.0” W), dense cerrado savanna (hereafter, DC - 12॰49'07.6” S, $51^{\circ} 46^{\prime} 12.3^{\prime \prime} \mathrm{W}$ ), and typical cerrado savanna (hereafter, TC - 12 ${ }^{\circ} 50^{\prime} 02.5^{\prime}$ ' S, $51^{\circ} 45^{\prime} 55.9^{\prime}$ W) - in the Cerrado-Amazon transition zone in Ribeirão Cascalheira municipality, Mato Grosso State, Brazil (see Maracahipes-Santos et al., 2015) (Figure 1). The region has well-defined rainy and dry periods, with mean annual precipitation of 1,400-1,600 mm and average temperatures of $24-25^{\circ} \mathrm{C}$ (Silva et al., 2008). The region's soils are dystrophic, when originating from sandstones and mudstones, or mesotrophic, when derived from rocks with a finer texture (Ratter et al., 1973).

\subsection{Data collection}

In each vegetation type, we established one 1-ha plot $(100 \mathrm{~m} \times 100 \mathrm{~m})$ divided into 25 permanent subplots of $20 \mathrm{~m} \times 20 \mathrm{~m}$. We recorded, identified, and marked with aluminum tags all the woody plants, including palms and lianas, with a basal diameter of $\geq 5 \mathrm{~cm}$ at a height of $30 \mathrm{~cm}\left(\mathrm{Bb}_{30 \mathrm{~cm}}\right)$ (Moro and Martins, 2011). For the palms, a minimum stem height of $50 \mathrm{~cm}$ was also used as the criterion of inclusion. Having made the phytosociological 


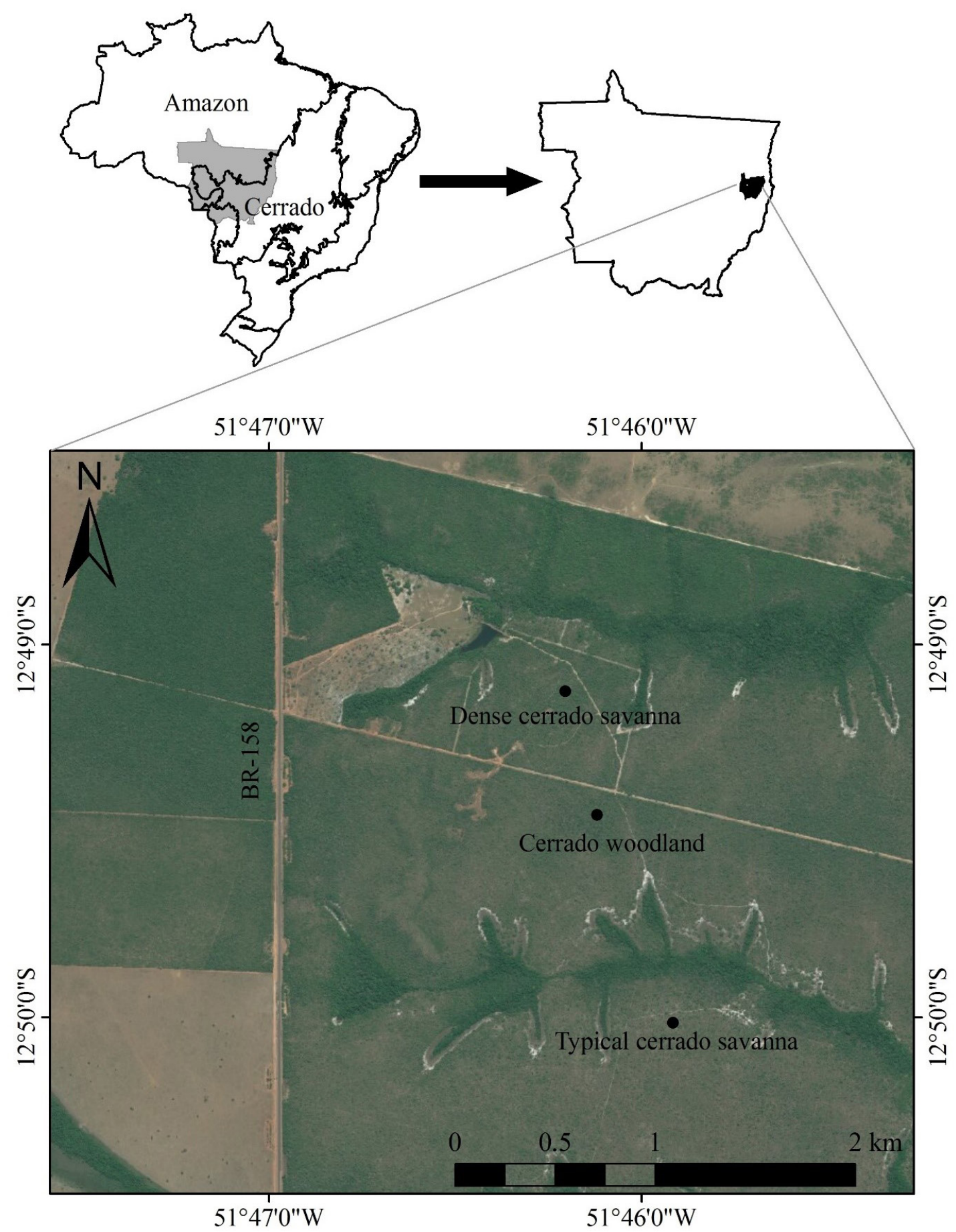

Figure 1. Location of the three Cerrado sites $(\bullet)$ surveyed in the Cerrado-Amazon transition in Ribeirão Cascalheira municipallity, Mato Grosso State, Brazil.

sampling, we created a matrix of species abundance for each subplot in each site. We obtained the geographic coordinates of the center of each subplot to create a spatial matrix. We collected three soil samples from each subplot at a depth of 0-20 cm. One sample was taken in the center of each subplot and the other two close to the opposite vertices to provide a composite sample for each subplot, which was used in the elaboration of the edaphic matrix for each subplot.

Whenever possible, we identified the individuals in the field. When necessary, we collected botanical samples of specimens for identification, through comparisons 
with the vouchers deposited in the NX Herbarium of the Universidade do Estado de Mato Grosso (UNEMAT) campus at Nova Xavantina, Brazil, as well as the specialized literature, and consultations with expert taxonomists (see Acknowledgments). We adopted the classification system of the Angiosperm Phylogeny Group (APG III, 2009) for the families, and updated the nomenclature of the taxa based on the Brazilian List of Plant Species (JBRJ, 2015; Zappi et al., 2015).

\subsection{Data analysis}

We classified the soils of the three phytophysiognomies a posteriori according to their texture (sand, clay, and silt content), base saturation, the alic character and acidity $(\mathrm{pH})$, based on the Sistema Brasileiro de Classificação de Solos (Embrapa, 2006). We compared the edaphic variables among sites using the non-parametric Kruskal-Wallis test $(\mathrm{H})$, given that the assumptions of normality of the residuals or the homogeneity of variances were not satisfied. For pairwise comparisons, we applied the Mann-Whitney test post hoc, with the Bonferroni correction.

We applied a Redundancy Analysis - RDA(Legendre et al., 2012) to evaluate the relationship between soils and the variation in the species composition and structure among each subplot in each physiognomy. In this analysis, we used the species composition and abundance matrix, which was adjusted using the Hellinger transformation (Legendre and Gallagher, 2001). To control for possible bias derived from spatial autocorrelation, we used spatial filters selected by a Variance Partition Analysis to adjust the edaphic matrix. This edaphic matrix with spatial filters was examined to eliminate variables with $\geq 0.7$ of autocorrelation. The significance of the groups was tested using a permutated Analysis of Variance - ANOVA (Legendre and Legendre, 2012). These analyses were run using vegan package (Oksanen et al., 2013) in the $\mathrm{R}$ environment (R Core Team, 2015), version 3.0.2.

We used a Variance Partition Analysis (Dray et al., 2012; Legendre et al., 2012) to evaluate the effects of the chemical and granulometric properties of the soil and spatial autocorrelation separately, as well as the effect of the shared portion of these predictor variables. For this, we removed the species that occur at only one site, following the routine proposed by Eisenlohr (2014). We applied the Hellinger transformation to the species matrix for the linear analyses (Legendre and Gallagher, 2001). We also standardized (decostand) the environmental data of the edaphic matrix. We generated Moran's Eigenvector Maps (MEMs) as spatial filters (Borcard et al., 2011; Legendre and Legendre, 2012), using the spatial matrix and then tested the significance of the MEMs using Moran's I test (Peres-Neto and Legendre, 2010; Borcard et al., 2011; Legendre et al., 2012). We ran the first Redundancy Analysis (RDA1) to progressively select (Blanchet et al., 2008) the spatial filters and a second analysis (RDA2), also progressive, to select the edaphic variables (Peres-Neto and Legendre, 2010). Finally, we tested the significance of the pure (edaphic and spatial) fractions using a permutated ANOVA (Legendre and Legendre, 2012). To validate the RDAs, we tested the linearity of the residuals (Peres-Neto and Legendre, 2010). The R environment, version 3.0.2 (R Core Team, 2015) was also used for these analyses, specifically, the vegan (Oksanen et al., 2013), ade4 (Dray and Dufour, 2007), packfor (Dray et al., 2013), spacemakeR (Dray, 2013), spdep (Bivand et al., 2013), venneuler (Wilkinson, 2011) and tripack packages (Renka et al., 2013).

\section{Results}

The soils of the plots in the three phytophysiognomies were classified following Embrapa (2006), as hyperdystrophic $(<35 \%$ base saturation), alic ( $\geq 50 \%$ saturation with aluminum), acidic ( $\mathrm{pH}<6.6)$ and sandy (mean of $870 \mathrm{~g} \cdot \mathrm{kg}^{-1}$ in the $\mathrm{CO}$ and $880 \mathrm{~g} \cdot \mathrm{kg}^{-1}$ in the DC and TC). We did not notice gradual increases or decreases in any of soil properties from the $\mathrm{CO}$ (a predominantly forested formation) to TC (a predominantly savanna formation) (Figure 2).

The Redundancy Analysis revealed that the CO, DC and TC subplots formed three distinct groups, based on the composition and abundance of species, and their relationship with the chemical and granulometric properties of the soils and spatial filters, or MEMs (Figure 3). The first ordination axis explained $13.4 \%$ of the variation in the structure/composition, and provided a clear separation of the subplots of the three phytophysiognomies. The predictor variables associated with each group presented pronounced differences (see Figure 3). The second axis explained 5.8\% of the variation in the structure and species composition and separated the DC subplots from all the others. The groups formed by the RDA were confirmed by the Analysis de Variance $\left(F_{(25,49)}=2.76 ; p<0.01\right)$.

The variation in the occurrence and abundance of the species among the three phytophysiognomies can be explained for by the purely spatial fraction $(13 \%)$ $\left(F_{(13)}=2.17 ; p<0.01\right)$, the purely edaphic fraction $(1 \%)$ $\left(F_{(6)}=1.23 ; p=0.01\right)$, and primarily by the combination of spatial and edaphic variables (spatially structured environment; (26\%)) (Figure 4). The complete model thus accounted for $40 \%$ of the variation, while $60 \%$ (residuals) remain unexplained (Figure 4).

\section{Discussion}

The use of soil categories considering the saturation of bases and aluminum, acidity and texture was not sufficient to distinguish the soils of the three phytophysiognomies surveyed in the present study. In this case, the simple classification of the soils does not appear to resolve questions related to the factors that determine the establishment of these phytophysiognomies in a given area or the variation in composition/structure observed in the vegetation types, as shown by the RDA (see Maracahipes-Santos et al., 2015). But even considering the edaphic properties on their own, no clear gradients (gradual changes) were found when one goes from the most well developed physiognomy, the CO, and the more open physiognomy, the TC, which could have represented a gradient of fertility or granulometry. 

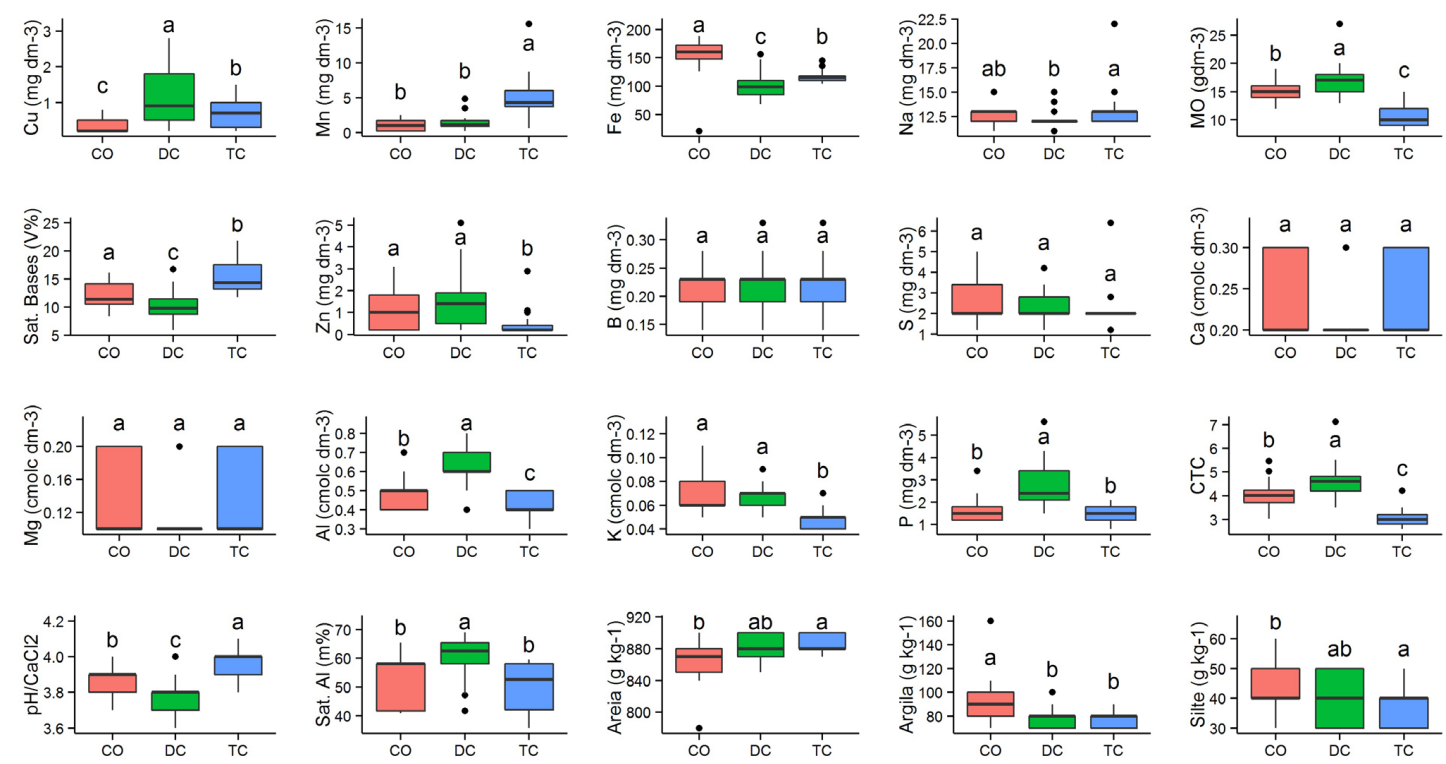

Figure 2. Comparison of the edaphic variables among the three Cerrado phytophysiognomies sampled in the Cerrado-Amazon transition in Ribeirão Cascalheira municipallity, Mato Grosso State, Brazil. Different letters and bar sizes indicate significant diferences in the Kruskall-Wallis test (5\%). The letters are arranged from the highest to lowest values.

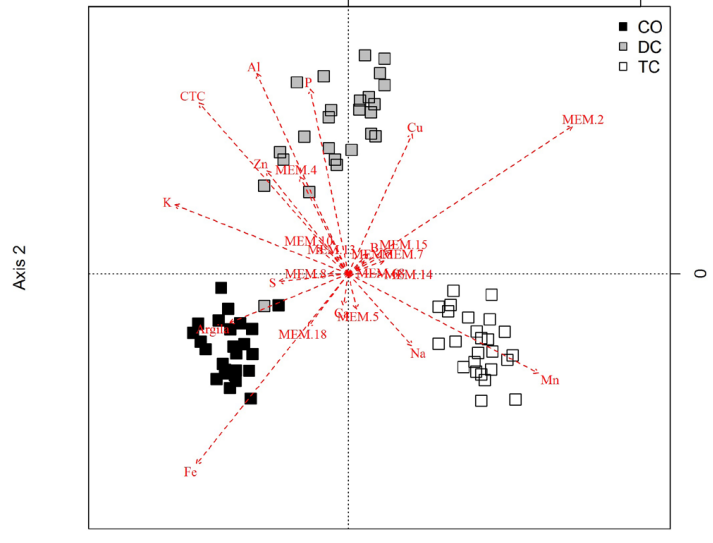

Axis 1

Figure 3. Redundancy Analysis of the woody species, physical-chemical properties, and spatial filters (MEMs) in the three Cerrado phytophysiognomies sampled in the Cerrado-Amazon transition in Ribeirão Cascalheira municipallity, Mato Grosso State, Brazil. Cerradão (CO), dense cerrado savanna (DC) and typical cerrado savanna (TC). MEM = Spatial filters; $\mathrm{Al}=$ Aluminum; $\mathrm{CTC}=$ Cation Exchange Capacity; $\mathrm{K}=$ Potassium; $\mathrm{Zn}=$ Zinc; $\mathrm{P}=$ Phosphorus; $\mathrm{Cu}=$ Copper; $\mathrm{B}=$ Boron; $\mathrm{Mn}=$ Manganese $; \mathrm{Na}=$ Sodium $; \mathrm{Ca}=$ Calcium $; \mathrm{S}=$ Sulfur.

Nevertheless, local gradients of modification in the structure and species composition among the studied physiognomies in response to edaphic properties and geographic spacing was indicated by the first ordination axis, a pattern also observed in a number of previous studies (Abreu et al., 2012;

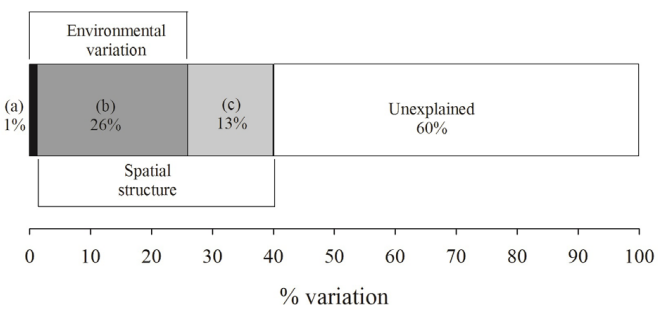

Figure 4. Partition of the variance of the influence of soil properties and spatial variables in the structure of three Cerrado phytophysiognomies sampled in the Cerrado-Amazon transition in Ribeirão Cascalheira municipallity, Mato Grosso State, Brazil. Pure fractions for soil and space only (a and c) were significant at $5 \%$ in the ANOVA.

Eiten, 1972; Oliveira-Filho and Ratter, 2002; Ribeiro and Walter, 2008). In this case, subtle and gradual changes among the three phytophysiognomies analyzed here can only be perceived through the systematic analysis of the interaction among the properties of the soil and geographic space, an approach that has been largely overlooked in studies comparing woody Cerrado communities.

In this case, despite the clear distinctions found in the structure and species composition of the three phytophysiognomies surveyed (Pinheiro and Durigan, 2012; Maracahipes-Santos et al., 2015), the causal factors are complex, and appear to depend on the interaction among the different chemical and granulometric properties of the soils, which have distinct effects. This complexity can be perceived in the second ordination axis, which separated the dense cerrado from the other two phytophysiognomies. 
The synergic effect of space together with the chemical and granulometric properties of the soil renders the soil-vegetation interaction even more complex. Marimon-Junior and Haridasan (2005) studied the cerradão and Cerrado sensu stricto in eastern Mato Grosso, but found no systematic relationship between soil and vegetation, although they did find differences among the classes of soil texture. Ruggiero et al. (2002) were also unable to distinguish Cerrado physiognomies based on edaphic characteristics. By contrast, Abreu et al. (2012), who investigated typical and stony cerrado in Goiás State, Brazil, found a clear relationship between the soil and plant species composition, and a much less pronounced link with geographic distance. We believe that, in situations where edaphic properties are more homogeneous, such as the present study, space is the determining factor, whereas in environments with highly distinct substrates (Abreu et al., 2012; Mews et al., 2016; Moro et al., 2015) the properties of the soil determine the distinct structure and species composition of the different Cerrado phytophysiognomies.

According to the classification of Ratter et al. (1973) and Oliveira-Filho and Ratter (2002), which considers species composition and edaphic properties, the cerradão surveyed in this study is of the dystrophic type, and thus similar to that studied by Marimon-Junior and Haridasan (2005), also in eastern Mato Grosso. This may account for the difficulty of distinguishing the cerradão from the other two phytophysiognomies, given that the soils of these communities are predominantly dystrophic and acidic, and have high levels of aluminum. Even where significant differences were found among the soils of the three physiognomies we studied, the variation was reduced in magnitude, such as the differences among sand, clay, and silt. Given this, we conclude that the dystrophic soils of the cerradão alone are not a good predictor of the vegetation phytophysiognomy, as it could not distinguish among the different phytophysiognomy locally found (cerradão, dense cerrado and typical cerrado).

The difficulty of distinguishing the vegetation types based on their soils is emphasized by the results of the variance partition analysis, which showed that, on a local scale, the vegetation of the CO, DC and TC was floristically heterogeneous, whereas the soils were relatively homogeneous (at least in nutritional terms) among habitats. In theory, this implies that other predictors (such as geographic variables and fire regime) can gain more important or do not have their importance masked. In the present study, the combined analysis of soils and space provided a better explanation of the structure and species composition of the woody vegetation of these communities, rather the analysis of each factor individually. Given this complexity, we would recommend that future studies include a larger number of environmental variables, in addition to space, and include other phytophysiognomies of the Cerrado, such as mesotrophic cerradão, which has soils that are considerably richer in nutrients (Ratter et al., 1973; Rodrigues and Araújo, 2013).
The distinction found among the three phytophysiognomies in structure and species composition, soils, and spacing indicate that the species turnover is an important mechanism to determine high levels of beta diversity in the cerrado. In this case, all three phytophysiognomies are essential for the maintenance of the biodiversity of the Cerrado in the Cerrado-Amazon transition (see, Maracahipes-Santos et al., 2015). Comparing areas of typical and stony Cerrado in Central Brazil, Mews et al. (2014) concluded that the flora of adjacent Cerrado phytophysiognomies is complementary. This perspective, these environments can be considered as different because to species turnover, and this replacement of some species by others reinforces the need for the development of integrated strategies for the preservation of these distinct habitats in projects for the creation or amplification of conservation units in the Cerrado (Baselga, 2010; Mews et al., 2014). The present study area is located within the region known as the "Arc of deforestation" (Nogueira et al., 2008), where anthropogenic impacts represent a major threat to the local biodiversity. As shown in other studies (Marimon et al., 2014; Marimon-Junior and Haridasan, 2005; Kunz et al., 2009; Gomes et al., 2011; Maracahipes-Santos et al., 2015), the species richness of trees and shrubs in the Cerrados of eastern Mato Grosso is among the biome's highest. Given the results of these studies, together with those of the present survey, we would recommend the consolidation of existing conservation units, and the creation of new areas that protect the distinct Cerrado phytophysiognomies found in the region of the Cerrado-Amazon transition (see Venn diagram, Maracahipes-Santos et al., 2015).

We conclude that the combined effects of the soils and geographic distance, rather than the individual influence of each factor, may account for a substantial portion of the variation found in the structure and species composition of the woody vegetation of the savanna and forest formations of the Cerrado-Amazon transition zone in Brazil. The complexity of the relationships found in the present study may also be at least partly a result of the ongoing anthropogenic impacts that affect the study region (Marimon et al., 2014), and also the fire regime (Coutinho, 2002) creating a highly dynamic scenario that affects all types of vegetation in different ways.

\section{Acknowledgements}

We are grateful to the Programa de Pós-graduação em Ecologia e Conservação, Universidade do Estado de Mato Grosso (UNEMAT) for financial and logistic support, CAPES for providing the first author with a graduate stipend, the "Tropical Biomes in Transition - TROBIT", PELD/CNPq (Pesquisa Ecológica de Longa Duração, site 15), and PROCAD UnB/UNEMAT (Project number 109/2007) for support during fieldwork, the proprietors of the farm Santa Marta, for their cooperation and authorization for the study. We would also like to thank the taxonomists Osny Tadeu de Aguiar and Natalia Macedo Ivanauskas of the São Paulo Forestry Institute, and Carolyn Elinore 
Barnes Proença of the Universidade de Brasília, for their input. We are also grateful to E.M. by help with the map.

\section{References}

ABREU, M.A., PINTO, J.R.R., MARACAHIPES, L., GOMES, L., OLIVEIRA, E.A., MARIMON, B.S., MARIMON-JUNIOR, B.H., FARIAS, J. and LENZA, E., 2012. Influence of edaphic variables on the floristic composition and structure of the treeshrub vegetation in typical and rocky outcrop cerrado areas in Serra Negra, Goiás State, Brazil. Brazilian Journal of Botany, vol. 35, no. 3, pp. 259-272. http://dx.doi.org/10.1590/S180699592012000300005 .

ANGIOSPERM PHYLOGENY GROUP - APG III, 2009. An update of the Angiosperm Phylogeny Group classification for the orders and families of flowering plants: APG III. Botanical Journal of the Linnean Society, vol. 161, no. 2, pp. 105-121. http://dx.doi.org/10.1111/j.1095-8339.2009.00996.x.

ARAÚJO, G.M. and HARIDASAN, M., 1988. A comparison of the nutritional status of two forest communities on mesotrophic and dystrophic soils in central Brazil. Communications in Soil Science and Plant Analysis, vol. 19, no. 7-12, pp. 1075-1089. http://dx.doi.org/10.1080/00103628809367996.

BASELGA, A., 2010. Partitioning the turnover and nestedness components of beta diversity. Global Ecology and Biogeography, vol. 19 , no. 55 , pp. 134-143. http://dx.doi.org/10.1111/j.14668238.2009.00490.x

BIVAND, R.S., HAUKE, J. and KOSSOWSKI, T., 2013. Computing the Jacobian in Gaussian spatial autoregressive models: An illustrated comparison of available methods. Geographical Analysis, vol. 45, no. 2, pp. 150-179. http://dx.doi.org/10.1111/ gean.12008.

BLANCHET, F.G., LEGENDRE, P. and BORCARD, D., 2008. Forward selection of explanatory variables. Ecology, vol. 89, no. 9, pp. 2623-2632. PMid:18831183. http://dx.doi.org/10.1890/070986.1 .

BORCARD, D., GILLET, F. and LEGENDRE, P., 2011. Numerical Ecology with R. New York: Springer. 302 p.

CARVALHO, G.H., BATALHA, M.A., CIANCIARUSO, M., SILVA, I.A. and PETCHEY, O.L., 2014. Are fire, soil fertility and toxicity, water availability, plant functional diversity, and litter decomposition related in a Neotropical savanna? Oecologia, vol. 175 , no. 3, pp. 923-935. PMid:24748157. http://dx.doi. org/10.1007/s00442-014-2937-3

COSTA, D.P. and PERALTA, D.F., 2015. Bryophytes diversity in Brazil. Rodriguésia, vol. 66, no. 4, pp. 1063-1071. http://dx.doi. org/10.1590/2175-7860201566409.

COUTINHO, L.M., 2002. O bioma do Cerrado. In: A. L. KLEIN, ed. Eugen Warming e o cerrado brasileiro: um século depois. São Paulo: Editora UNESP; Imprensa Oficial do Estado, pp. 77-91.

DRAY, S. and DUFOUR, A.B., 2007. The ade4 package: implementing the duality diagram for ecologists. Journal of Statistical Software, vol. 22, no. 4, pp. 1-20. PMid:21494410. http://dx.doi.org/10.18637/jss.v022.i04.

DRAY, S., 2013 [viewed 10 October 2015]. spacemakeR: Spatial modelling. R package version 0.0-5/r113 [online]. Available from: http://R-Forge.R-project.org/projects/sedar/
DRAY, S., PÉLISSIER, R., COUTERON, P., FORTIN, M.J., LEGENDRE, P., PERES-NETO, P.R., BELLIER, E., BIVAND, R., BLANCHET, F.G., DE CÁCERES, M., DUFOUR, A.B., HEEGAARD, E., JOMBART, T., MUNOZ, F., OKSANEN, J., THIOULOUSE, J. and WAGNER, H.H., 2012. Community ecology in the age of multivariate multiscale spatial analysis. Ecological Monographs, vol. 82, no. 3, pp. 257-275. http://dx.doi. org/10.1890/11-1183.1.

DRAY, S., LEGENDRE, P. and BLANCHET, G., 2013. packfor: Forward Selection with permutation (Canoco p.46). R package version 0.0-8/r109 [online]. Available from: http://R-Forge.Rproject.org/projects/sedar/

EISENLOHR, P.V., 2014. Persisting challenges in multiple models: a note on commonly unnoticed issues regarding collinearity and spatial structure of ecological data. Brazilian Journal of Biology = Revista Brasileira de Biologia, vol. 37, no. 4, pp. 365-371. http://dx.doi.org./10.1590/1519-6984.17413.

EITEN, G., 1972. The cerrado vegetation of Brazil. Botanical Review, vol. 38, no. 2, pp. 201-341. http://dx.doi.org/10.1007/ BF02859158.

EMPRESA BRASILEIRA DE PESQUISA AGROPECUÁRIA - EMBRAPA. Centro Nacional de Pesquisa de Solos, 2006. Sistema brasileiro de classificação de solos. 2 nd ed. Rio de Janeiro: EMBRAPA. 306 p.

FELFILI, J.M., FELFILI, M.C., NOGUEIRA, P.E., ARMAS, J.F.S., FARIÑAS, M.R., NUNES, M., SILVA-JÚNIOR, M.C., REZENDE, A.V. and FAGG, C.W., 2008. Padrões fitogeográficos e sua relação com sistemas de terra no bioma Cerrado. In: S.M. SANO, S.P. ALMEIDA and J.F. RIBEIRO, eds. Cerrado: ecologia eflora. Brasília: Embrapa Informação Tecnológica, pp. 213-228.

FURLEY, P.A., 1999. The nature and diversity of neotropical savanna vegetation with particular reference to the Brazilian cerrados. Global Ecology and Biogeography, vol. 8, no. 3-4, pp. 223-241. http://dx.doi.org/10.1046/j.1466-822X.1999.00142.x.

GOMES, L., LENZA, E., MARACAHIPES, L., MARIMON, B.S. and OLIVEIRA, E.A., 2011. Comparações florísticas e estruturais entre duas comunidades lenhosas de cerrado típico e cerrado rupestre, Mato Grosso, Brasil. Acta Botanica Brasílica, vol. 25 , no. 4 , pp. $865-875$. http://dx.doi.org/10.1590/S010233062011000400013.

HARIDASAN, M., 2007. Solos. In: J.M. FELFILI, A.V. REZENDE, M.C. SILVA-JÚNIOR, eds. Biogeografia do bioma Cerrado: vegetação e solos da Chapada dos Veadeiros. Brasília: Finatec, pp. 27-43

HOFFMANN, W.A., GEIGER, E.L., GOTSCH, S.G., ROSSATTO, D.R., SILVA, L.C.R., LAU, O.L., HARIDASAN, M. and FRANCO, A.C., 2012. Ecological thresholds at the savannaforest boundary: how plant traits, resources and fire govern the distribution of tropical biomes. Ecology Letters, vol. 15, no. 7, pp. 759-768. PMid:22554474. http://dx.doi.org/10.1111/j.14610248.2012.01789.x.

JARDIM BOTÂNICO DO RIO DE JANEIRO - JBRJ, 2015 [viewed 10 October 2015]. Lista de Espécies da Flora do Brasil [online]. Available from: http://floradobrasil.jbrj.gov.br

KUNZ, S.H., IVANAUSKAS, N.M. and MARTINS, S.V., 2009. Estrutura fitossociológica de uma área de cerradão em Canarana, Estado do Mato Grosso, Brasil. Acta Scientiarum: Biological Sciences, vol. 31, no. 3, pp. 255-261. http://dx.doi.org/10.4025/ actascibiolsci.v31i3.1625. 
LEGENDRE, P. and GALLAGHER, E., 2001. Ecologically meaningful transformations for ordination of species data. Oecologia, vol. 129, no. 2, pp. 271-280. http://dx.doi.org/10.1007/ s004420100716.

LEGENDRE, P. and LEGENDRE, L., 2012. Numerical ecology. 3rd ed. Oxford: Elsevier. 1006 p.

LEGENDRE, P., BORCARD, D. and ROBERTS, D.W., 2012. Variation partitioning involving orthogonal spatial eigenfunction submodels. Ecology, vol. 93, no. 5, pp. 1234-1240. PMid:22764509. http://dx.doi.org/10.1890/11-2028.1.

LEGENDRE, P., DALE, M.R.T., FORTIN, M.J., GUREVITCH, J., HOHN, M. and MYERS, D., 2002. The consequences of special structure for the design and analysis of ecological field surveys. Ecography, vol. 25, no. 2, pp. 601-615. http://dx.doi. org/10.1034/j.1600-0587.2002.250508.x.

MARACAHIPES-SANTOS, L., LENZA, E., SANTOS, J.O., MARIMON, B.S., EISENLOHR, P.V., MARIMON-JUNIOR, B.H. and FELDPAUSCH, T.R., 2015. Diversity, floristic composition, and structure of the woody vegetation of the Cerrado in the Cerrado-Amazon transition zone in Mato Grosso, Brazil. Brazilian Journal of Botany, vol. 38, no. 1, pp. 1-11. http://dx.doi. org/10.1007/s40415-015-0186-2.

MARIMON, B.S., MARIMON-JUNIOR, B.H., FELDPAUSCH, T.R., OLIVEIRA-SANTOS, C., MEWS, H.A., LOPEZGONZALEZ, G., LLOYD, J., FRANCZAK, D.D., OLIVEIRA, E.A., MARACAHIPES, L., MIGUEL, A., LENZA, E. and PHILLIPS, O.L., 2014. Disequilibrium and hyperdynamic tree turnover at the forest-cerrado transition zone in southern Amazonia. Plant Ecology \& Diversity, vol. 7, no. 1-2, pp. 281-292. http:// dx.doi.org/10.1080/17550874.2013.818072.

MARIMON-JUNIOR, B.H. and HARIDASAN, M., 2005. Comparação da vegetação arbórea e características edáficas de um cerradão e um cerrado sensu stricto em áreas adjacentes sobre solo distrófico no leste de Mato Grosso, Brasil. Acta Botanica Brasílica, vol. 19, no. 4, pp. 913-926. http://dx.doi.org/10.1590/ S0102-33062005000400026.

MENDONÇA, R.C., FELFILI, J.M., WALTER, B.T., SILVAJÚNIOR, M.C., REZENDE, A.V., FILGUEIRAS, T.S., NOGUEIRA, P.E. and FAGG, C.W., 2008. Flora Vascular do bioma Cerrado: checklist com 12.356 espécies. In: S.M. SANO, S.P. ALMEIDA and J.F. RIBEIRO, eds. Cerrado: ecologia e flora. Planaltina: Embrapa Cerrados, pp. 421-1279.

MEWS, H., PINTO, J.R.R., EISENLOHR, P.V. and LENZA, E., 2014. Does size matter? Conservation implications of differing woody population sizes with equivalent occurrence and diversity of species for threatened savanna habitats. Biodiversity and Conservation, vol. 23, no. 5, pp. 1119-1131. http://dx.doi. org/10.1007/s10531-014-0651-4.

MEWS, H.A., PINTO, J.R.R., EISENLOHR, P.V. and LENZA, E., 2016. No evidence of intrinsic spatial processes driving Neotropical savanna vegetation on different substrates. Biotropica, vol. 48, no. 4, pp. 433-442. http://dx.doi.org/10.1111/btp.12313.

MORO, M.F. and MARTINS, F.R., 2011. Métodos de levantamento do componente arbóreo-arbustivo. In: J.M. FELFILI, P.V. EISENLORH, M.M.R.F. MELO, L.A. ANDRADE and J.A.A. MEIRA-NETO, eds. Fitossociologia no Brasil: métodos e estudos de casos. Viçosa: Universidade Federal de Viçosa, pp. 174-212.

MORO, M.F., SILVA, I.A., ARAÚJO, F.S., LUGHADHA, E.N. and MEAGHER, T.R., 2015. The role of edaphic environment and climate in structuring phylogenetic pattern in seasonally dry tropical plant communities. PLoS One, vol. 10, no. 3, pp. 1-18. PMid:25798584. http://dx.doi.org/10.1371/journal.pone.0119166.

MOTTA, P.E.F., CARVALHO-FILHO, A., KER, J.C., PEREIRA, N.R., CARVALHO, J.W. and BLANCANEAUX, P., 2002. Relações solo-superfície geomórfica e evolução da paisagem em uma área do Planalto Central Brasileiro. Pesquisa Agropecuaria Brasileira, vol. 37, no. 6, pp. 869-878. http://dx.doi.org/10.1590/ S0100-204X2002000600017.

NEVES, D.M., DEXTER, K.G., PENNINGTON, R.T., BUENO, M.L. and OLIVEIRA FILHO, A.T., 2015. Environmental and historical controls of floristic composition across the South American Dry Diagonal. Journal of Biogeography, vol. 42, no. 8, pp. 1566-1576. http://dx.doi.org/10.1111/jbi.12529.

NOGUEIRA, E.M., NELSON, B.W., FEARNSIDE, P.M., FRANÇA, M.B. and OLIVEIRA, C.A., 2008. Tree height in Brazil's 'arc of deforestation': Shorter trees in south and southwest Amazonia imply lower biomass. Forest Ecology and Management, vol. 255, no. 7, pp. 2963-2972. http://dx.doi.org/10.1016/j.foreco.2008.02.002.

OKSANEN, J., BLANCHET, F.G., KINDT, R., LEGENDRE, P., MINCHIN, P.R., O'HARA, R.B., SIMPSON, G.L., SOLYMOS, P., STEVENS, M.H.H. and WAGNER, H., 2013 [viewed 10 October 2015]. vegan: Community Ecology Package. R package version 2.0-10 [online]. Available from: http://CRAN.R-project. org $/$ package $=$ vegan

OLIVEIRA-FILHO, A.T. and RATTER, J.A., 1995. A study of the origin of central Brazilian forests by the analysis of plant species distribution patterns. Edinburgh Journal of Botany, vol. 52, no. 2, pp. 141-194. http://dx.doi.org/10.1017/S0960428600000949.

OLIVEIRA-FILHO, A.T. and RATTER, J.A., 2002. Vegetation Physiognomies and Woody Flora of the Cerrado Biome. In: P.S. OLIVEIRA and R.J. MARQUIS, eds. The Cerrados of Brazil: ecology and natural history of a neotropical savanna. New York: Columbia University Press, pp. 91-120.

OLIVEIRA-FILHO, A.T., SHEPHERD, G.D., MARTINS, F.R. and STUBBLEBINE, W.H., 1989. Environmental factors affecting physiognomic and floristic variation in an area of cerrado in Central Brazil. Journal of Tropical Ecology, vol. 5, no. 4, pp. 413-431. http://dx.doi.org/10.1017/S0266467400003862.

PERES-NETO, P.R. and LEGENDRE, P., 2010. Estimating and controlling for spatial structure in the study of ecological communities. Global Ecology and Biogeography, vol. 19, no. 2, pp. 174-184. http://dx.doi.org/10.1111/j.1466-8238.2009.00506.x.

PINHEIRO, E.S. and DURIGAN, G., 2012. Diferenças florísticas e estruturais entre fitofisionomias do Cerrado em Assis, SP, Brasil. Revista Árvore, vol. 36, no. 1, pp. 181-193. http://dx.doi. org/10.1590/S0100-67622012000100019.

PRADO, J., SYLVESTRE, L.D.S., LABIAK, P.H., WINDISCH, P.G., SALINO, A., BARROS, I.C.L., HIRAI, R.Y., ALMEIDA, T.E., SANTIAGO, A.C.P., KIELING-RUBIO, M.A., PEREIRA, A.F.N., ØLLGAARD, B., RAMOS, C.G.V., MICKEL, J.T., DITTRICH, V.A.O., MYNSSEN, C.M., SCHWARTSBURD, P.B., CONDACK, J.P.S., PEREIRA, J.B.S. and MATOS, F.B., 2015. Diversity of ferns and lycophytes in Brazil. Rodriguésia, vol. 66, no. 4, pp. 1073-1083. http://dx.doi.org/10.1590/21757860201566410

R DEVELOPMENT CORE TEAM, 2015 [viewed 10 October 2015]. $R$ : a language and environment for statistical computing [online]. Vienna: R Foundation for Statistical Computing. Available from: http://www.R-project.org 
RATTER, J.A., RICHARDS, P.W., ARGENT, G. and GIFFORD, D.R., 1973. Observations on the vegetation of the northeastern Mato Grosso. I. The woody vegetation types of the XavantinaCachimbo Expedition area. Philosophical Transactions of the Royal Society of London. Series B, Biological Sciences, vol. 266, no. 880, pp. 449-492. http://dx.doi.org/10.1098/rstb.1973.0053.

REATTO, A., CORREIA, J.R. and SPERA, S.T., 2008. Solos do Bioma do Cerrado: aspectos pedológicos. In: S.M. SANO, S.P. ALMEIDA and J.F. RIBEIRO, eds. Cerrado: ecologia e flora. Planaltina: Embrapa-CPAC, pp. 107-149.

RENKA, R.J., EGLEN, S., ZUYEV, S. and WHITE, D., 2013 [viewed 10 October 2015]. tripack: Triangulation of irregularly spaced data. Fortran code. R package version 1.3-6 [online]. Available from: http://CRAN.R-project.org/package=tripack

RIBEIRO, J.F. and WALTER, B.M.T., 2008. As principais fitofisionomias do bioma Cerrado. In: S.M. SANO, S.P. ALMEIDA and J.F. RIBEIRO, eds. Cerrado: ecologia e flora. Planaltina: Embrapa-CPAC, pp. 151-212.

RODRIGUES, R.F. and ARAÚJO, G.M., 2013. Estrutura da vegetação e características edáficas de um cerradão em solo distrófico e em solo mesotrófico no Triângulo Mineiro. Bioscience Journal, vol. 29, no. 6, pp. 2013-2029.

RUGGIERO, P.G.C., BATALHA, M.A., PIVELlO, V.R. and MEIRELLES, S.T., 2002. Soil-vegetation relationships in cerrado (Brazilian savanna) and semideciduous forest, Southeastern Brazil. Plant Ecology, vol. 160, no. 1, pp. 1-16. http://dx.doi. org/10.1023/A:1015819219386.

SILVA, F.A.M., ASSAD, E.D. and EVANGELISTA, B.A., 2008. Caracterização Climática do Bioma Cerrado. In: S.M. SANO, S.P. ALMEIDA and J.F. RIBEIRO, eds. Cerrado: ecologia e flora. Planaltina: Embrapa-CPAC, pp. 67-88.

SILVA, J.F., FARIÑAS, M.R., FELFILI, J.M. and KLINK, C.A., 2006. Spatial heterogeneity, land use and conservation in the cerrado region of Brazil. Journal of Biogeography, vol. 33, no. 3, pp. 536-548. http://dx.doi.org/10.1111/j.1365-2699.2005.01422.x.

WILKINSON, L., 2011[viewed 10 October 2015]. venneuler: Venn and Euler Diagrams. R package version 1.1-0 [online]. Available from: http://CRAN.R-project.org/package=venneuler

ZAPPI, D.C., FILARDI, F.L.R., LEITMAN, P., SOUZA, V.C., WALTER, B.M.T., PIRANI, J.R., MORIM, M.P., QUEIROZ, L.P., CAVALCANTI, T.B., MANSANO, V.F., FORZZA, R.C., ABREU, M.C., ACEVEDO-RODRÍGUEZ, P., AGRA, M.F., ALMEIDA, E.B. Jr., ALMEIDA, G.S.S., ALMEIDA, R.F., ALVES, F.M., ALVES, M., ALVES-ARAUJO, A., AMARAL, M.C.E., AMORIM, A.M., AMORIM, B., ANDRADE, I.M., ANDREATA, R.H.P., ANDRINO, C.O., ANUNCIAÇÃO, E.A., AONA, L.Y.S., ARANGUREN, Y., ARANHA FILHO, J.L.M., ARAÚJO, A.O., ARAÚJO, A.A.M., ARAÚJO, D., ARBO, M.M., ASSIS, L., ASSIS, M.C., ASSUNÇÃO, V.A., ATHIÊ-SOUZA, S.M., AZEVEDO, C.O., BAITELLO, J.B., BARBERENA, F.F.V.A., BARBOSA, M.R.V., BARROS, F., BARROS, L.A.V., BARROS, M.J.F., BAUMGRATZ, J.F.A., BERNACCI, L.C., BERRY, P.E., BIGIO, N.C., BIRAL, L., BITTRICH, V., BORGES, R.A.X., BORTOLUZZI, R.L.C., BOVE, C.P., BOVINI, M.G., BRAGA, J.M.A., BRAZ, D.M., BRINGEL JUNIOR, J.B.A., BRUNIERA, C.P., BUTURI, C.V., CABRAL, E., CABRAL, F.N., CADDAH, M.K., CAIRES, C.S., CALAZANS, L.S.B., CALIÓ, M.F., CAMARGO, R.A., CAMPBELL, L., CANTO-DOROW, T.S., CARAUTA, J.P.P., CARDIEL, J.M., CARDOSO, D.B.O.S., CARDOSO, L.J.T., CARNEIRO, C.R., CARNEIRO, C.E., CARNEIRO-TORRES, D.S., CARRIJO, T.T., CARUZO, M.B.R.,
CARVALHO, M.L.S., CARVALHO-SILVA, M., CASTELLO, A.C.D., CAVALHEIRO, L., CERVI, A.C., CHACON, R.G., CHAUTEMS, A., CHIAVEGATTO, B., CHUKR, N.S., COELHO, A.A.O.P., COELHO, M.A.N., COELHO, R.L.G., CORDEIRO, I., CORDULA, E., CORNEJO, X., CÔRTES, A.L.A., COSTA, A.F., COSTA, F.N., COSTA, J.A.S., COSTA, L.C., COSTA-E-SILVA, M.B., COSTA-LIMA, J.L., COTA, M.R.C., COUTO, R.S., DALY, D.C., DE STEFANO, R.D., DE TONI, K., DEMATTEIS, M., DETTKE, G.A., DI MAIO, F.R., DÓREA, M.C., DUARTE, M.C., DUTILH, J.H.A., DUTRA, V.F., ECHTERNACHT, L., EGGERS, L., ESTEVES, G., EZCURRA, C., FALCÃO JUNIOR, M.J.A., FERES, F., FERNANDES, J.M., FERREIRA, D.M.C., FERREIRA, F.M., FERREIRA, G.E., FERREIRA, P.P.A., FERREIRA, S.C., FERRUCCI, M.S., FIASCHI, P., FILGUEIRAS, T.S., FIRENS, M., FLORES, A.S., FORERO, E., FORSTER, W., FORTUNAPEREZ, A.P., FORTUNATO, R.H., FRAGA, C.N., FRANÇA, F., FRANCENER, A., FREITAS, J., FREITAS, M.F., FRITSCH, P.W., FURTADO, S.G., GAGLIOTI, A.L., GARCIA, F.C.P., GERMANO FILHO, P., GIACOMIN, L., GIL, A.S.B., GIULIETTI, A.M., A.P.GODOY, S., GOLDENBERG, R., GOMES DA COSTA, G.A., GOMES, M., GOMES-KLEIN, V.L., GONÇALVES, E.G., GRAHAM, S., GROPPO, M., GUEDES, J.S., GUIMARÃES, L.R.S., GUIMARÃES, P.J.F., GUIMARÃES, E.F., GUTIERREZ, R., HARLEY, R., HASSEMER, G., HATTORI, E.K.O., HEFLER, S.M., HEIDEN, G., HENDERSON, A., HENSOLD, N., HIEPKO, P., HOLANDA, A.S.S., IGANCI, J.R.V., IMIG, D.C., INDRIUNAS, A., JACQUES, E.L., JARDIM, J.G., KAMER, H.M., KAMEYAMA, C., KINOSHITA, L.S., KIRIZAWA, M., KLITGAARD, B.B., KOCH, I., KOSCHNITZKE, C., KRAUSS, N.P., KRIEBEL, R., KUNTZ, J., LAROCCA, J., LEAL, E.S., LEWIS, G.P., LIMA, C.T., LIMA, H.C., LIMA, I.B., LIMA, L.F.G., LIMA, L.C.P., LIMA, L.R., LIMA, L.F.P., LIMA, R.B., LÍRIO, E.J., LIRO, R.M., LLERAS, E., LOBÃO, A., LOEUILLE, B., LOHMANN, L.G., LOIOLA, M.I.B., LOMBARDI, J.A., LONGHI-WAGNER, H.M., LOPES, R.C., LORENCINI, T.S., LOUZADA, R.B., LOVO, J., LOZANO, E.D., LUCAS, E., LUDTKE, R., LUZ, C.L., MAAS, P., MACHADO, A.F.P., MACIAS, L., MACIEL, J.R., MAGENTA, M.A.G., MAMEDE, M.C.H., MANOEL, E.A., MARCHIORETTO, M.S., MARQUES, J.S., MARQUETE, N., MARQUETE, R., MARTINELLI, G., MARTINS DA SILVA, R.C.V., MARTINS, Â.B., MARTINS, E.R., MARTINS, M.L.L., MARTINS, M.V., MARTINS, R.C., MATIAS, L.Q., MAYA-L, C.A., MAYO, S., MAZINE, F., MEDEIROS, D., MEDEIROS, E.S., MEDEIROS, H., MEDEIROS, J.D., MEIRELES, J.E., MELLO-SILVA, R., MELO, A., MELO, A.L., MELO, E., MELO, J.I.M., MENEZES, C.G., MENINI NETO, L., MENTZ, L.A., MEZZONATO, A.C., MICHELANGELI, F.A., MILWARD-DE-AZEVEDO, M.A., MIOTTO, S.T.S., MIRANDA, V.F.O., MONDIN, C.A., MONGE, M., MONTEIRO, D., MONTEIRO, R.F., MORAES, M.D., MORAES, P.L.R., MORI, S.A., MOTA, A.C., MOTA, N.F.O., MOURA, T.M., MULGURA, M., NAKAJIMA, J.N., NARDY, C., NASCIMENTO JÚNIOR, J.E., NOBLICK, L., NUNES, T.S., O'LEARY, N., OLIVEIRA, A.S., OLIVEIRA, C.T., OLIVEIRA, J.A., OLIVEIRA, L.S.D., OLIVEIRA, M.L.A.A., OLIVEIRA, R.C., OLIVEIRA, R.S., OLIVEIRA, R.P., PAIXÃO-SOUZA, B., PARRA, L.R., PASINI, E., PASTORE, J.F.B., PASTORE, M., PAULA-SOUZA, J., PEDERNEIRAS, L.C., PEIXOTO, A.L., PELISSARI, G., PELLEGRINI, M.O.O., PENNINGTON, T., PERDIZ, R.O., PEREIRA, A.C.M., PEREIRA, M.S., PEREIRA, R.A.S., PESSOA, C., PESSOA, E.M., PESSOA, M.C.R., PINTO, L.J.S., PINTO, R.B., PONTES, T.A., PRANCE, G.T., PROENÇA, C., PROFICE, S.R., PSCHEIDT, A.C., QUEIROZ, G.A., QUEIROZ, R.T., QUINET, A., RAINER, H., RAMOS, E., RANDO, J.G., RAPINI, A., REGINATO, M., REIS, I.P., REIS, P.A., RIBEIRO, A.R.O., RIBEIRO, J.E.L.S., RIINA, R., RITTER, M.R., RIVADAVIA, F., ROCHA, A.E.S., ROCHA, 
M.J.R., RODRIGUES, I.M.C., RODRIGUES, K.F., RODRIGUES, R.S., RODRIGUES, R.S., RODRIGUES, V.T., RODRIGUES, W., ROMANIUC NETO, S., ROMÃO, G.O., ROMERO, R., ROQUE, N., ROSA, P., ROSSI, L., SÁ, C.F.C., SAAVEDRA, M.M., SAKA, M., SAKURAGUI, C.M., SALAS, R.M., SALES, M.F., SALIMENA, F.R.G., SAMPAIO, D., SANCHO, G., SANO, P.T., SANTOS, A., SANTOS, É.P., SANTOS, J.S., SANTOS, M.R., SANTOS-GONÇALVES, A.P., SANTOS-SILVA, F., SÃOMATEUS, W., SARAIVA, D.P., SARIDAKIS, D.P., SARTORI, Â.L.B., SCALON, V.R., SCHNEIDER, Â., SEBASTIANI, R., SECCO, R.S., SENNA, L., SENNA-VALLE, L., SHIRASUNA, R.T., SILVA FILHO, P.J.S., SILVA, A.S., SILVA, C., SILVA, G.A.R., SILVA, G.O., SILVA, M.C.R., SILVA, M.J., SILVA, M.J., SILVA, O.L.M., SILVA, R.A.P., SILVA, S.R., SILVA, T.R.S., SILVA-GONÇALVES, K.C., SILVA-LUZ, C.L., SIMÃOBIANCHINI, R., SIMÕES, A.O., SIMPSON, B., SINISCALCHI, C.M., SIQUEIRA FILHO, J.A., SIQUEIRA, C.E., SIQUEIRA, J.C., SMITH, N.P., SNAK, C., SOARES NETO, R.L., SOARES, K.P.,
SOARES, M.V.B., SOARES, M.L., SOARES, P.N., SOBRAL, M., SODRÉ, R.C., SOMNER, G.V., SOTHERS, C.A., SOUSA, D.J.L., SOUZA, E.B., SOUZA, É.R., SOUZA, M., SOUZA, M.L.D.R., SOUZA-BUTURI, F.O., SPINA, A.P., STAPF, M.N.S., STEFANO, M.V., STEHMANN, J.R., STEINMANN, V., TAKEUCHI, C., TAYLOR, C.M., TAYLOR, N.P., TELES, A.M., TEMPONI, L.G., TERRA-ARAUJO, M.H., THODE, V., THOMAS, W.W., TISSOT-SQUALLI, M.L., TORKE, B.M., TORRES, R.B., TOZZI, A.M.G.A., TRAD, R.J., TREVISAN, R., TROVÓ, M., VALLS, J.F.M., VAZ, A.M.S.F., VERSIEUX, L., VIANA, P.L., VIANNA FILHO, M.D.M., VIEIRA, A.O.S., VIEIRA, D.D., VIGNOLI-SILVA, M., VILAR, T., VINHOS, F., WALLNÖFER, B., WANDERLEY, M.G.L., WASSHAUSEN, D., WATANABE, M.T.C., WEIGEND, M., WELKER, C.A.D., WOODGYER, E., XIFREDA, C.C., YAMAMOTO, K., ZANIN, A., ZENNI, R.D. and ZICKEL, C.S., 2015. Growing knowledge: an overview of Seed Plant diversity in Brazil. Rodriguésia, vol. 66, no. 4, pp. 1085-1113. http://dx.doi.org/10.1590/2175-7860201566411. 